Commentary/Bickerton: Language bioprogram hypothesis

\title{
Socioprogrammed linguistics
}

William J. Samarin

Department of Linguistics, University of Toronto, Toronto, Ontario M5S 1A1, Canada

On this occasion I am concerned less with whether or not Bickerton can argue successfully for innate "cognitive devices" and a "processing component" as fundamental human endowments than with whether evidence for the hypothesis is found in the so-called creoles. Alternatively, one can assess Bickerton's argument entirely with respect to its ability to explain the ostensible similarities in these languages, since he claims that his "is one, and so far the only, explanation." On the one hand is a single Hawaiian "creole" and on the other a whole group of languages whose speakers have an African ancestry. The sets are presented as having self-evident integrity, but they remain highly problematic. (Bickerton has preempted the word creole, for what he calls "true creoles," misleading talking of "all creoles" when he means only the languages he uses.) The question lies not with the linguistic data, the contemporary forms of which are of easy access, but with their sociohistorical interpretation.

Taking his Hawaiian data, Bickerton assumes a "pidgin" that is degenerate and anarchic as the only antecedent to his Hawaiian Creole. (Others use the pidgin for a language with a stable grammatical system.) While attempting elsewhere to isolate these putative idioms chronologically and evolutionarily, he cannot be said to have made an altogether convincing case. No one - not even Reinecke (1969) - has given proper attention to the linguistic aspects and consequences of the role that the Sandwich (now Hawaiian) Islands played in Pacific trade during the 18th and 19th centuries. In 1842, for example, there were reported to have been 500 Hawaiians in the service of the Hudson's Bay Company west of the Rockies and "Chinooks" (presumably Indians from the Colombia River area) in Hawiii (Society 1956, pp. 105, 133, 137; also Samarin, in preparation). For his own period (1876-1920) Bickerton has not explained (a) how the "extremely rudimentary" idiom was used and (b) whether or not and to what degree its speakers interacted with the speakers of the coexisting creole. Without such sociolinguistic identification his pidgin and creole must remain artifacts of his analysis.

The Atlantic creoles figure more prominently in Bickertoris argument than the Hawaiian although they present greater problems in historiography. He seems to assume that each of the creoles had its own antecedent "pidgin," ignoring the possibility (indeed, probability) of considerable contact between speakers of many different varieties of New World speech. He has not demonstrated that these idioms were formed in the 1650 s, nor that they arose very early in their history. Therefore (and for other reasons deducible from Bickerton's argument), the cla'm that a "fit" has been established between the distribution of linguistic features and "the circumstances under which individual creoles arose" is a specious one. In other words, Bicker- 
ton has failed to "provide evidence that the right speakers were in the right places at the right times" for these languages to have developed - a charge he lays against those who would account for the transmission of certain features from African languages. Reversing Figure 3 from right to left suggests a different and quite defensible historical development.

Elsewhere Bickerton's argument is as simplistic as it is in some respects deficient. It is simply not true that "at the beginning of colonization in any colony, dominant-language speakers probably always outnumbered speakers of substratum languages." My detailed documentation of the personnel involved in the colonization of the Congo and Ubangi river basins in the last quarter of the 19th century (work in progress) reveals Europeans to have been vastly outnumbered by their foreign African workers. Even if Bickerton means only "plantation" systems, a distinction which he once invoked (in a personal communication) to dismiss an argument I put forward (Samarin 1980), he would have to characterize the contexts where the new idioms emerged. What he is desperately looking for, of course, is something parallel to what he believes he has discovered in Hawaii. Extreme multilingualism is what he needs, and the absence of viable language targets.

He simply asserts that "hundreds, perhaps thousands of different languages" were involved; and "perhaps as many as a thousand typologically diverse" languages. This could not possibly mean that this many languages were involved in each of the creole's evolution. The assertion is patently hyperbolic. A reasonable number of languages for all of Africa - the last I heard was 2,000 .

Baker's demographic analysis (Baker \& Corne 1982) - just the kind that is needed for the explanation of the origins of pidgins and creoles - would seem to provide Bickerton with precious data, but it must be remembered that Baker tells the story of only one language on one island, which was integrated into much smaller socioeconomic system. The so-called pidginization index derived by Bickerton is only a metaphor of a measure, since it suggests but does not give information. It is, moreover, at best a gross metaphor. The number of speakers of the European language proportionate to all others at a given time (Figure 2) is only one factor in language contact. One must consider frequency and nature of contact, among others. There is no a priori reason why a few persons could not have had an impact disproportionate to their numbers; indeed, that is the more typical situation.

Inexplicably omitted from the index are the children, protagonists - if not deus ex machina - of the drama of language crcation. How, we ask, did children in 28 years - a figure that Corne deduces from Baker's data (Baker \& Corne 1982, pp. 120, 248) - produce Mauritian Creole? The answer must come from analyses that demographers and human geographers might provide with respect to fertility and mortality, with due regard to epidemiology, in a slave-plantation economy. (And Baker's analysis is itself subject to critical interpretation.)

Even where Bickerton might have been able to provide a convincing analysis of the Hawaiian infant speech community, he has not done so. He has only now admitted, under crossexamination, so to speak, that these children could have had available to them fully developed languages. Then he makes the astounding assertion that, in any case, when children are acquiring a pidgin as their first language, they cannot make use of normal language material. (Clever debater that Bickerton is, he makes his opponent responsible for proving the contrary!) $\mathrm{He}$ has yet to cope with the factor of variability. Not all children heard the same pidgin: Some must certainly have been more developed than other forms.

Bickerton's argument is not strengthened by his disbelief in attempts to explain Atlantic creole grammars in terms of African origins. His refusal to consider this possibility is an arbitrary one: requiring the comparison of "whole systems." Why Alleyne's comparisons (1980a) are discounted is not made clear.
(What makes Alleyne's work inadequate is that it is vague about both African linguistic sources for creole features and about the socioeconomic context of creolization.) As an Africanist, I find much - even in the geographically remote Gbeya language (Samarin 1966) - that is too similar to be purely accidental.

Bickerton's assertion that implicit in what one might call the Africanist point of view is the belief that "languages can be made by throwing together a heterogeneous set of items" is indefensible. I do not know any contemporary linguist who would take this position. Nonetheless, it should be admitted that parts of a pidgin, possibly important parts, can be absorbed from languages other than those that figure most importantly, as is the case in Sango of the negative (from "stray" speakers of Mongo) and the copula (apparently from Kongo) (Samarin 1982; 1984).

Whatever the merits of Bickerton's hypothesis for advancing our understanding of the neurological bases for language, it certainly has not advanced the explanation of how and why pidgins and creoles emerge. If language is said to be a consequence of adaptation on the part of human beings, that adaptation ineluctably includes the function language bas in making possible human interaction. There is that "program" too that makes homo sapiens a social creature.

\section{ACKNOWLEDGMENTS}

Financial support for the research that led to the writing of this paper came in whole or in part from the University of Toronto on more than one occasion (from both the International Studies Programme and the Humanities and Social Research Programme), the American Philosophical Society, the Social Sciences Research Council (USA), and the Social Sciences and Humanities Research Council of Canada, Jack K. Chambers made remarks on this commentary that improved it considerably.

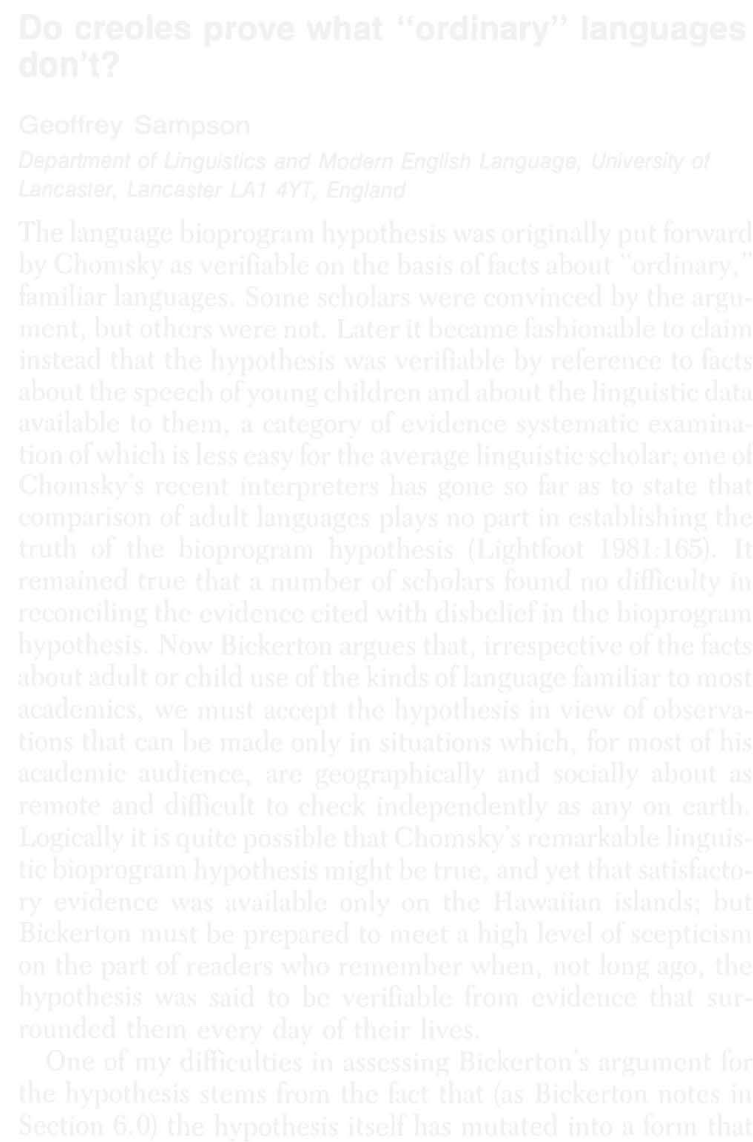

